УДК 341.24:334.784(4/5)

DOI: $10.18384 / 2310-6794-2015-3-12-26$

Глотов С.A.

Государственная Дума Федерального Собрания РФ

\title{
Григорьев ИА.
}

Российский федеральный центр судебной экспертизы при Министерстве юстиции РФ по Московской области

\section{ПРАВОВАЯ СИСТЕМА ЕВРАЗИЙСКОГО ЭКОНОМИЧЕСКОГО СОЮЗА: ПОСТАНОВКА ПРОБЛЕМЫ}

Аннотация. В 2014 г. Россия, Белоруссия и Казахстан заключили договор о создании Евразийского экономического союза (ЕАЭС), который затем вступил в силу. В 2015 г. к ЕАЭС присоединилась Армения и Киргизия. В статье идет речь о фрормирующемся праве Евразийского экономического союза (ЕАЭС). Предлагается концепция правовой системы ЕАЭС и ее основные составляющие. Анализируется деятельность государств-членов Союза по созданию и развитию таможенного и иного законодательства. В перспективе может быть создано «парламентское измерение» ЕАЭС.

Ключевые слова: Евразийский экономический союз, правовая система ЕАЭС, таможенное законодательство, евразийская интеграция.

\section{S. Glotov}

Doctor of Law, Professor

Deputy of the State Duma of the Federal Assembly of the Russian Federation

\section{Grigoriev}

Head of the Federal Budgetary Institution

The Russian Federal Center of Forensic Science under the Ministry of Justice of the Russian Federation (the Moscow Region Branch)

\section{THE LEGAL SYSTEM OF THE EURASIAN ECONOMIC UNION: STATING THE PROBLEM}

Abstract. In 2014 Russia, Belarus and Kazakhstan reached an agreement on the Eurasian Economic Community (EAEC) which soon came into effect. In 2015 Armenia and Kyrgyzstan joined the same organization. The article is concerned with the emerging law of the Eurasian Economic Community and proposes a concept of EAEC legal system and its main components. It reviews the measures taken by the Member States of the Community to draft and develop customs and other legislations. The authors consider parliamentarism as a possible dimension of EAEC.

Key words: the Eurasian Economic Community, EAEC legal system, customs legislation, Eurasian integration.

(с) Глотов С.А., Григорьев И.А., 2015. 
1. Новейшая политическая история знает немало примеров различного рода союзов $^{1}$, в том числе интеграции государств на постсоветском пространстве. Более чем двадцатилетняя практика показывает, что движение в направлении интеграции в области экономической политики, культуры, права, социальной сфере и т. д. со стороны государств может быть «разноскоростным», и сегодня на базе СНГ - ЕврАзЭС сформировалась группа государств - Россия, Белоруссия, Казахстан, Армения и Киргизия, которые не только заявили о стремлении жить в Таможенном союзе, но и пойти дальше: иметь единое экономическое пространство (речь идет о свободном перемещении товаров, капиталов, услуг, рабочей силы, а также более тесном союзе стран), единый экономический союз.

Ранее, как известно, главами РСФСР, Белоруссии и Украины было создано Содружество Независимых Государств путем подписания в Вискулях под Брестом (Белоруссия) 8 декабря 1991 г. соглашения об СНГ. В Соглашении, в том числе, говорилось о том, что Советский Союз прекратил свое существование как субъект международного права и геополитической реальности. Затем к СНГ присоединились другие бывшие республики СССР, за исключением прибалтийских, а 21 декабря 1991 г. была принята Алма-

${ }^{1}$ В современном мире существует 26 региональных экономических объединений: 5 экономических и валютных союзов (ЕС, Экономическое Сообщество стран Центральной Африки (ЭкоЦАС) и др.) 4 общих рынка (Евразийское экономическое пространство, Карибское сообщество и общий рынок) и др.), 6 таможенных союзов (ЕС, Совет сотрудничества арабских государств Персидского залива и др.), 11 зон свободной торговли (Африканский Союз, СНГ и др.) [1].
Атинская декларация, закрепляющая цели и принципы Содружества. Устав СНГ был принят 23 января 1993 г. 18 октября 2011 г. 8 государств (Россия, Украина, Белоруссия, Казахстан, Армения, Киргизия, Молдавия и Таджикистан) подписали Договор о зоне свободной торговли. Затем одни государства-члены СНГ пошли по пути свертывания своего участия в работе этой организации (Грузия, Туркмения, Украина), другие, наоборот, - более тесного сотрудничества, создали Евразийское экономическое сообщество (Россия, Белоруссия, Казахстан, Таджикистан и др.) [6].

С 1 января 2015 г. вступил в силу Договор о Евразийском экономическом союзе (ЕАЭС) [7], призванный обеспечить экономический прогресс путем совместных действий Республики Беларусь, Республики Казахстан и Российской Федерации (затем к ним присоединилась Республика Армения, планирует вступить Киргизская Республика), направленных на развитие стоящих перед этими странами общих задач по устойчивому экономическому развитию, всесторонней модернизации и усилении конкурентоспособности национальных экономик в рамках глобальной экономики [12].

В своем выступлении с Посланием Федеральному Собранию РФ (2014) Президент России В.В. Путин, говоря о базовых принципах ЕАЭС, отметил: «Прежде всего, это равноправие, прагматизм и взаимное уважение. Это сохранение национальной самобытности и государственного суверенитета всех стран-участниц. Убежден, что тесная кооперация станет мощным источником развития всех участников Евразийского Союза» [10]. 
Действительно, все страны-участницы Евразийского экономического союза дорожат своим суверенитетом. Вместе с тем, согласно Конституциям, действующим в своих странах, они могут вступать в различные союзы. Например, в ст. 79 Конституции России говорится: «Российская Федерация может участвовать в межгосударственных объединениях и передавать им часть своих полномочий, в соответствии с международными договорами, если это не влечет ограничения прав и свобод человека и гражданина и не противоречит основам конституционного строя Российской Федерации» ${ }^{1}$.

В ст. 8 Белорусской Конституции говорится: «Республика Беларусь в соответствии с нормами международного права может на добровольной основе входить в межгосударственные образования и выходить из них. Не допускается заключение международных договоров, которые противоречат Конституции» ${ }^{2}$.

2. Как известно, в начале пути к современному этапу интеграции был «проект» о формировании Евразийского Союза Государств (ЕАС), представленный Президентом Казахстана Н.А. Назарбаевым в МГУ им. М.В. Ломоносова еще в марте

${ }^{1}$ Не следует забывать и о том, что Декларация о государственном суверенитете РСФСР от 12 июня 1990 г., принятая Первым Съездом народных депутатов РСФСР, содержит ст. 6: «Российская Советская Федеративная Социалистическая Республика объединяется с другими республиками в союз на основе договора...». Торжественно провозглашая государственный суверенитет, Декларация также констатировала решимость создать демократическое правовое государство в составе обновленного Союза ССР.

2 См.: Конституция Республики Беларусь 1994 года (с изменениями и дополнениями, принятыми на республиканских референдумах 24 ноября 1996 г., 17 октября 2004 г.). Минск: Амалфея, 2013.
1994 г. [9] 3 . Создать ЕАС предполагалось в целях стабильности и безопасности на основе реально работающих экономических и политических связей с учетом разного уровня экономического развития, демократизации стран и т. д. Этот Союз должен был стать ответом на дезинтеграцию, кризисное состояние экономики и финансов на постсоветском пространстве. Как показала практика, на это понадобилось немало времени - почти десять лет для создания Евразийского экономического сообщества и пятнадцать лет для провозглашения Евразийского экономического союза $[4 ; 5 ; 6 ; 7]$.

Между тем ранее 70 лет народы стран жили вместе в составе СССР, совместно вели хозяйственную и иную деятельность, созданный народно-хозяйственный комплекс Советского Союза демонстрировал иногда высокие темпы роста (табл. 1, 2).

\section{Таблииа 1}

\section{Рост общего объема промышленной продукции в отдельных союзных республиках СССР $(1913=1)^{4}$}

\begin{tabular}{|l|c|c|c|}
\hline Республика & $\mathbf{1 9 4 0}$ & $\mathbf{1 9 6 0}$ & $\mathbf{1 9 7 7}$ \\
\hline СССР & 7,7 & 40 & 145 \\
\hline РСФСР & 8,7 & 43 & 144 \\
\hline Украинская ССР & 7,3 & 27 & 95 \\
\hline Белорусская ССР & 8,1 & 34 & 192 \\
\hline Казахская ССР & 7,8 & 57 & 223 \\
\hline Киргизская ССР & 9,9 & 61 & 311 \\
\hline Таджикская ССР & 8,8 & 38 & 131 \\
\hline Армянская ССР & 8,7 & 68 & 311 \\
\hline
\end{tabular}

${ }^{3}$ Сама идеология евразийства активно формировалась более 100 лет назад при участии Н.С. Трубецкого, П. Савицкого, Н. Алексеева, Л. Красавина, Л. Гумилева, Г. Вернадского и других ученых, писателей, практиков.

${ }^{4}$ См. подробно: СССР. Энциклопедический справочник / Гл. ред. А.М. Прохоров. М.: Советская энциклопедия, 1979. С. 207-245. 
Несложно заметить, что уже в 90-е годы будущие участники ЕАЭС развивались достаточно динамично (табл. $1,2,3$ ).

Таблица 2

Розничный товарооборот государственной и кооперативной торговли, включая общественное питание, по некоторым союзным республикам СССР (млрд. руб.)

\begin{tabular}{|l|c|c|}
\hline \multicolumn{1}{|c|}{ Республика } & $\mathbf{1 9 4 0}$ & $\mathbf{1 9 7 7}$ \\
\hline СССР & 18,0 & 230,6 \\
\hline РСФСР & 11,7 & 133,5 \\
\hline Украинская ССР & 3,2 & 40,4 \\
\hline Белорусская ССР & 0,5 & 8,2 \\
\hline Казахская ССР & 0,4 & 11,0 \\
\hline Киргизская ССР & 0,1 & 2,2 \\
\hline Таджикская ССР & 0,1 & 1,9 \\
\hline Армянская ССР & 0,1 & 2,1 \\
\hline
\end{tabular}

3. Кратко основные вехи интеграции в рамках Евразийского пространства можно представить следующим образом:

Основные этапы экономической интеграции в рамках Евразийского Экономического Сообщества - ЕврАзЭС $[1 ; 3 ; 13]$

Подписание Договора об учреждении

Евразийского экономического сообщества

10.10.2000 (5 стран - Россия, Белоруссия, Казахстан, Киргизия, Таджикистан)

Принятие решения о создании ТС Учреждение

06.10.2007 наднационального органа - Комиссии

Таможенного союза

Завершение формирования Таможенного союза

01.07.2011 РБ, РК и РФ

Подписание документов, формирующих

09.12.2010 Единое экономическое пространство (ЕЭП).

Вступление в силу документов (3 страны)

Разработка и подписание 55 документов,

01.01.2012 реализация более 70 мероприятий правительств сторон (3 страны)

Договор о создании Евразийского

$2011-2015$ экономического союза (подписан 29 мая 2014

года в Астане, вступил в силу 1 января 2015 года)
Формирование Таможенного союза и Единого экономического пространства

Создание Таможенного союза трех государств - РБ, РК и РФ

ФС РФ ратифицировало 42 документа из 51, составляющих правовую базу ТС

Начало функционирования ЕЭП

Обеспечение полноформатного функционирования ЕЭП

Определение этапов и сроков создания экономического союза, порядка его работь 
Таблица 3

Показатели численности населения, размера ВВП, уровня инфляции, безработицы и торгового баланса в России, Белоруссии и Казахстане

\begin{tabular}{|l|c|c|c|c|c|c|}
\hline \multicolumn{1}{|c|}{ Страны } & $\begin{array}{c}\text { Население, } \\
\text { млн. } \\
\text { человек }\end{array}$ & $\begin{array}{c}\text { Размер реального } \\
\text { ВВП, млрд. } \\
\text { долларов США }\end{array}$ & $\begin{array}{c}\text { Размер ВВП на } \\
\text { душу населения, } \\
\text { тыс. долларов США }\end{array}$ & $\begin{array}{c}\text { Инфля- } \\
\text { ция, \% }\end{array}$ & $\begin{array}{c}\text { уровень } \\
\text { безрабо- } \\
\text { тицы, \% }\end{array}$ & $\begin{array}{c}\text { Торговый баланс, } \\
\text { млрд. долларов } \\
\text { США }\end{array}$ \\
\hline Россия & 142.5 & 2113.0 & 14.8 & 6.8 & 5.8 & 174.0 \\
\hline Белоруссия & 9.6 & 69.2 & 7.2 & 19.0 & 0.0 & -3.1 \\
\hline Казахстан & 17.7 & 224.9 & 12.7 & 5.8 & 5.3 & 35.2 \\
\hline
\end{tabular}

Таким образом, к 1 января 2015 г. стал функционировать Евразийский экономический союз (ЕАЭС), занимающий восьмое место в мире по численности населения - 176252830 человек, первое по территории -

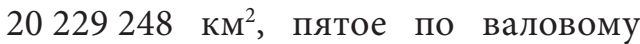
внутреннему продукту (ВВП (ППС)) - 4 077,1 млрд. дол. США (по данным МВФ). ЕАЭС стал международной организацией экономической интеграции, обладающей международной правосубъектностью. Как отмечалось выше, в ней обеспечивается свободное передвижение товаров, капиталов, услуг и рабочей силы, проводится скоординированная (общая) экономическая политика государствучастников [14].

В соответствии с Декларацией о евразийской экономической интеграции (от 18.11.2011) [4] к 1 января 2015 г. была завершена кодификация международных договоров, созданы правовые основы (нормативная база) ЕАЭС, проведены следующие мероприятия:

- осуществлена балансировка (согласование) макроэкономической, бюджетной и конкурентной политики;

- $\quad$ проведены некоторые реформы рынка труда, капиталов, товаров и услуг;

- продолжено создание евразийских сетей в сферах энергетики, транспорта и телекоммуникаций;
- реализовывался потенциал Таможенного союза и Единого экономического пространства.

23 января 2015 г. Государственная Дума ФС РФ приняла (затем Президент РФ подписал) Федеральный закон 3 февраля 2015 г. № 1-Ф3 «О ратификации Договора о прекращении деятельности Евразийского экономического сообщества», в связи с началом работы Евразийского экономического союза.

4. В рамках ЕЭП должны функционировать однотипные механизмы регулирования экономики, основанные на рыночных принципах, гармонизации и унификации норм и права. В рамках Единого экономического пространства России - Белоруссии - Казахстана были приняты документы, обеспечивающие:

а) свободу передвижения рабочей силы:

- Соглашение о сотрудничестве по противодействию нелегальной трудовой миграции из третьих государств;

- Соглашение о правовом статусе трудящихся-мигрантов и членов их семей;

б) свободу движения услуг: Соглашение о торговле услугами и инвестициях в государствах-участниках ЕЭП;

в) свободу движения капитала:

- Соглашение о создании условий на финансовых рынках для обеспечения свободного движения капитала;

- Соглашение о свободных принципах валютной политики; 
г) согласованную экономическую политику:

- Соглашение о согласованной макроэкономической политике;

- Соглашение о единых принципах и правилах регулирования деятельности субъектов естественных монополий;

- Соглашение о порядке организации управления, функционирования и развития общего рынка нефти и нефтепродуктов РБ, РК и РФ;

- Соглашение о единых принципах и правилах конкуренции и др.

В течение 2011 г. был принят пакет из 17 базовых соглашений по созданию Единого экономического пространства. Эти соглашения вступили в силу в 2012 г., что означает начало работы ЕЭП в составе РБ - РК - РФ.

В период 2011-2015 гг. приняты еще 13 международных договоров и более 40 других документов (протоколов, методик и т. п.) для функционирования ЕЭП.

Результатом этих и иных интеграционных действий должен стать экономический рост.

Таблиия 4

\section{Интеграционный эффект от создания ЕЭП ${ }^{1}$}

\begin{tabular}{|l|c|c|c|c|c|c|}
\hline & $\begin{array}{c}\text { Динамика ВВП } \\
(2011 \text { г.=1,0) }\end{array}$ & $\begin{array}{c}\text { ВВП (млрд. долл. } \\
\text { США) 2011 г. }\end{array}$ \\
\hline & 2015 & 2020 & 2030 & 2015 & 2020 & 2030 \\
\hline Россия & 1.25 & 1.60 & 2.47 & 2380.3 & 3809.0 & 9411.1 \\
\hline Беларусь & 1.18 & 1.37 & 1.77 & 65.3 & 89.4 & 157.9 \\
\hline Казахстан & 1.19 & 1.51 & 2.36 & 224.0 & 338.5 & 797.6 \\
\hline \multicolumn{7}{|c|}{ Создание ЕЭП } \\
\hline & 2015 & 2020 & 2030 & 2015 & 2020 & 2030 \\
\hline Россия & 1.27 & 1.62 & 2.53 & 2411 & 3905 & 9890 \\
\hline Беларусь & 1.23 & 1.44 & 3.23 & 67.8 & 97.4 & 314.3 \\
\hline Казахстан & 1.22 & 1.53 & 2.63 & 229.5 & 350.8 & 921.1 \\
\hline ИТОГО & & & & 38.65 & 116.76 & 758.96 \\
\hline
\end{tabular}

\footnotetext{
${ }^{1}$ Источник - расчеты ИНП РАН.
}

Как показывают проведенные расчеты, создание ЕЭП в составе трех стран дает суммарный интегральный эффект к 2030 г. свыше 750 млрд. дол. США в ценах 2011 г. (табл. 4). Наиболее значительными интеграционные процессы являются для Белоруссии, чей ВВП к 2030 г. окажется в 3,2 раза выше уровня 2011 г., по сравнению с ростом в 1,7 раза в сценарии отсутствия интеграции. Суммарный выигрыш Казахстана от создания Единого экономического пространства, а затем и Евразийского экономического союза оценивается в период 2011-2030 гг. свыше 120 млрд. дол. в ценах 2011 г., а Россия к 2030 г. обеспечивает дополнительный прирост ВВП чуть менее 500 млрд. дол.

Уже в 2010 г. объем взаимной торговли в рамках Таможенного союза увеличился на 25,6 \%, в 2011 г. этот прирост составил $35 \%$ [1, с. 182-183, c. 190-193].

Одним из ключевых факторов евразийской интеграции выступает формирование ее договорно-правовой базы, включая, конечно, Таможенный союз (ТС) $[4 ; 5 ; 6 ; 7 ; 8 ; 14 ; 15$; 16]. Непосредственное формирование и развитие международно-правовой базы ТС началось с 2007 года, когда Межгосударственный совет ЕврАзЭС (РБ - КР - РФ) был наделен статусом Высшего органа Таможенного союза постоянно действующего регулирующего органа, хотя соглашения о Таможенном Союзе принимались 6 января и 20 января 1995 г., а 26 февраля 1999 г. был заключен Договор о Таможенном союзе и Едином экономическом пространстве.

Разработчики идеи и практики создания ЕАЭС двигались от «ре- 
жима свободной торговли» (отмена таможенных пошлин и других ограничительных мер в торговле товарами, произведенными на территории государств-членов) к «таможенному союзу» (создание единой таможенной территории, в пределах которой обеспечивается свободное движение товаров, как произведенных на данной территории, так и ввезенных из третьих стран и выпущенных в свободное обращение) и «единому экономическому пространству» (свободное перемещение товаров, капиталов, услуг и рабочей силы), а затем и к единому экономическому союзу.

Правовые документы Таможенного союза - Единого экономического пространства - Евразийского экономического сообщества - Евразийского экономического союза весьма объемны по своему содержанию и сложны в понимании (табл. 5).

Примерами могут служить Единый таможенный тариф Таможенного союза РБ - РК - РФ, утвержденный Решением Межгосударственного совета Евразийского экономического сообщества (высшего органа Таможенного союза) от 27 ноября 2009 г. № 18 и Решением Комиссии Таможенного союза от 27 ноября 2009 г. № 130 (с последующими изменениями и дополнениями) [8].

Речь идет о своде ставок таможенных пошлин, применяемых к тарифам, вводимым на Единой таможенной территории трех стран, систематизированных в соответствии с Единой товарной номенклатурой внешнеэкономической деятельности Таможенного союза (в «книжном варианте» он занимает 760 страниц).

Единый таможенный тариф Таможенного союза включает 21 раздел, в том числе раздел I «Живые животные: продукты животного происхождения», раздел II «Продукты растительного происхождения», раздел III «Жиры и масла», раздел IV «Готовые пищевые продукты, алкоголь и табак», раздел V «Минеральные продукты», и замыкает его раздел XXI - «Произведения искусства, предметы коллекционирования и антиквариата» [8].

Основой правовой системы таможенного регулирования на таможенной территории ТС является Таможенный кодекс ТС [16], договор о котором был подписан главами государств-членов ТС 27 ноября 2009 г. Кодекс состоит из двух частей (общей и специальной), включает 8 разделов, 50 глав и 372 статьи. Нормы Кодекса устанавливают на таможенной территории ТС:

- единые правила таможенного контроля;

- единые правила декларирования товаров;

- единый порядок применения таможенных процедур к товарам;

- единую методологию определения таможенной стоимости;

- унифицированные формы документов, используемых при осуществлении таможенных операций и проведении таможенного контроля.

В настоящее время данный кодекс перерабатывается.

В целом, право ЕАЭС составляют целый ряд документов, основополагающим из которых является договор о Евразийском экономическом союзе.

Право ЕАЭС составляют:

- Договор о ЕАЭС;

- международные договоры, заключенные в рамках Союза;

- международные договоры ЕАЭС с третьими странами; 
- решения и распоряжения Высшего Евразийского экономического совета, Евразийского межправительственного совета и Евразийской экономической комиссии;

- приоритет в разрешении противоречий принадлежит Договору о ЕАЭС;

- решения высших органов ЕАЭС исполняются государствами-членами в порядке, предусмотренном их национальными законодательствами.

В целом, в процессе разработки права и практики Таможенного союза - ЕврАзЭС - ЕАЭС использовался как опыт правового регулирования в рамках Европейского Союза, так и BТО, СНГ, других международных организаций, в целом международного права $[2 ; 11 ; 17]$.
Так, в праве ЕС интерес попрежнему будут представлять такие разделы (компоненты), как: а) право внутреннего рынка Европейского сообщества; б) общий таможенный тариф Европейского Сообщества; в) антимонопольная политика и право конкуренции ЕС; г) правовое регулирование юридических лиц (корпоративное право ЕС); д) правовое регулирование экономического и валютного союза; е) правовые основы финансирования системы ЕC; ж) налоговое право Европейского союза; з) правовые основы транспортной политики и транспортного законодательства ЕC; и) правовое регулирование.

Таблииза 5

\section{Формирование договорно-правовой базы Таможенного союза}

\begin{tabular}{|l|l|}
\hline Октябрь 2007 г. & $\begin{array}{l}\text { Договора (на уровне глав государств): } \\
\text { - условия создания и статус ТС; } \\
\text { - институциональная структура ТС; } \\
\text { - механизм присоединения членов ЕврАзЭС }\end{array}$ \\
\hline Январь 2008 г. & $\begin{array}{l}\text { 9 Договоров (на уровне глав правительств): } \\
\text { - установление единого регулирования торговли с третьими странами; } \\
\text { - унификация таможенного администрирования; } \\
\text { - передача Комиссии ТС полномочий по регулированию внешнеторговой } \\
\text { деятельности }\end{array}$ \\
\hline Декабрь 2008 г. & $\begin{array}{l}\text { 16 Договоров (на уровне глав правительств): } \\
\text { - вопросы таможенно-тарифного регулирования; } \\
\text { - таможенное администрирование }\end{array}$ \\
\hline $2009-2010$ гг. & $\begin{array}{l}\text { Продолжение формирования правовой базы ТС. Принято } 42 \text { договора, } 14 \text { из } \\
\text { которых вступили в силу, в том числе: } \\
\text { - Таможенный кодекс (вступил в силу } 1 \text { июля } 2010 \text { г.); } \\
\text { - о нетарифном регулировании; } \\
\text { - о техническом регулировании; } \\
\text { - по вопросам налогообложения }\end{array}$ \\
\hline
\end{tabular}


5. Правовая система АЕЭС, по мнению авторов, может выглядеть следующим образом:

Схема 1.

Правовая система Евразийского экономического союза и ее составляющие

\section{1. Право ЕАЭС}

как совокупность юридических норм обязательного и рекомендательного характера, их официальные источники (договоры, декларации, соглашения, технические регламенты, правила, стандарты и др.), действующие в государствах-членах Союза, составляющие нормативно-правовую базу Таможенного союза и Единого экономического пространства, евразийской интеграции. Это разработка законодательства ЕАЭС, создание и развитие основ правосудия.

\section{1. Право ЕАЭС составляют:}

- Договор о Евразийском экономическом союзе 2014 года (вступил в силу с 1 января 2015 года). Ранее - Декларация о евразийской экономической интеграции, принятая главами России, Белоруссии и Казахстана 18 января 2011 года и другие основополагающие акты;

- международные договоры, заключенные в рамках Союза;

- международные договоры ЕАЭС с третьими странами;

- решения и распоряжения Высшего Евразийского экономического совета, Евразийского межправительственного совета и Евразийской экономической комиссии;

- Таможенный кодекс Таможенного союза и технические регламенты;

- решения Суда ЕАЭС (Суда Союза).

Приоритет в разрешении возникающих противоречий принадлежит Договору о ЕАЭС.

\section{2. Основные направления разработки законодательства} (нормативно-правовой базы) Евразийского экономического союза

- кодификация международных договоров, составляющих нормативно-правовую базу

Таможенного союза и Единого экономического пространства как правовой основы создания ЕАЭС;

- разработка законодательства в области сбалансированной макроэкономической, бюджетной

и конкурентной политики;

- совершенствование законодательства Союза в областях: реформы рынка труда, капиталов, товаров и услуг, проведения единой внешнеторговой политики;

- развитие нормативно-правовой базы функционирования транспортных, энергетических и телекоммуникационных сетей;

- законодательное обеспечение деятельности (полномочий) руководящих органов ЕАЭС, Суда

Союза;

- обновление и унификация национальных законодательств;

- поиск совместных решений проблем правового и иного характера, возникающих в связи с динамичным развитием ЕАЭС, принятием в Союз новых членов и осуществлением совместных антикризисных мер (их разработка и мониторинг). 


\section{3. Учет специфических особенностей развития законодательства}

- в Таможенном союзе РБ - РК - РФ (Таможенный кодекс ТС) необходимо унифицировались не только таможенное законодательство, но и иные виды законодательства - гражданское, банковское, налоговое, которые остались до настоящего времени исключительно национальными;

- сложности, связанные с делегированием на наднациональный уровень таких функций, как: ведение торговой политики и единого таможенного тарифа, таможенного регулирования; унификация таможенного режима; ведение переговоров с внешними партнерами, введение и применение защитных мер, нетарифных ограничений во внешней торговле; введение единой системы ветеринарного, санитарного и фитосанитарного контроля;

- проблемные вопросы гармонизации функций, остающихся в ведении национальных органов; разработка проблематики проведения единой внешнеторговой политики, включая:

- создание общего рынка товаров (в том числе устранение барьеров и ограничений для доступа

к нему;

- переход к расчетам в национальных валютах, создание в перспективе единой валюты и

развитие законодательства о валютном регулировании и валютном контроле;

- совершенствование налогового законодательства (в том числе области косвенных налогов),

законодательства об экспортном контроле;

- развитие законодательства о таможенной службе;

- совершенствование уголовного и административного законодательства в области

правонарушений, связанных с незаконным перемещением товаров через таможенную границу, и др.

1.4. Открытие новых направлений в развитии законодательства (сфер деятельности) ЕАЭС в первую очередь, в сфере гуманитарного, человеческого измерения, прав и свобод человека, развития образования, науки и культуры, социальной сферы, социального обеспечения и обслуживания населения.

\section{2. Юридическая практика}

деятельности политико-правовых институтов ЕврАзЭС - ЕАЭС в области экономических интеграционных процессов на евразийском пространстве, а затем и в других сферах.

\section{1. Учет особенностей нормотворческого процесса на постсоветском пространстве}

Например, принятие в рамках Евразийского экономического сообщества (ЕврАзЭС) пакета из 22 международных договоров, формирующих основы договорно-правовой базы Таможенного союза (ТС), имеющих отложенный статус (отложенный характер введения в действие).

Договоры вводили в действие отдельными решениями высшего исполнительного органа Межгоссовета ЕврАзЭС (РБ - РК - РФ - Киргизия - Таджикистан):

- создание Таможенного союза (2008-2011) в рамках Евразийского экономического сообщества, реализация Договора о создании Единой таможенной территории и формировании

Таможенного союза (2007), Договора о Комиссии ТС и Протокола о порядке вступления в силу международных договоров, направленных на формирование договорно-правовой базы Таможенного союза, учет в законотворческой и практической работе нормативной базы ВТО; - принятие в 2007 году Таможенного кодекса Таможенного союза и начало его применения с 1 июля 2010 года, утверждение в декабре 2009 г. Единого таможенного тарифа Таможенного Союза (РБ - РК - РФ) (ЕТТ) (с последующими дополнениями);

- формирование Единой таможенной территории:

а) 01.01.2010 - введение Единого таможенно-тарифного и нетарифного регулирования (отмена таможенного оформления товаров во взаимной торговле РБ - РК - РФ);

б) 01.07.2010 - введение механизма зачисления и распределения ввозных таможенных пошлин; в) 01.02.20111 - перенос контроля на внешнюю границу РБ, введение в действие Таможенного кодекса Таможенного союза; перенос таможенного контроля на внешнюю границу РК. Из 52 международных договоров ТС вступили в силу и применялись 43 (7 утратили актуальность). 


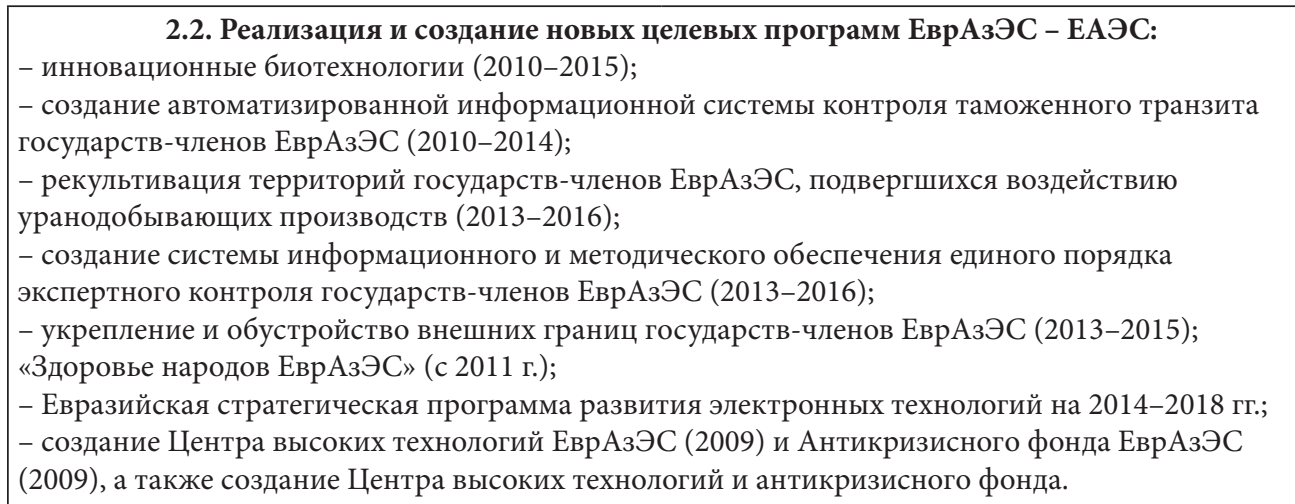

2.3. Евразийская интеграция до недавнего времени (2015 г.) носила чисто экономической характер, тем самым определяя границы делегирования национального суверенитета на наднациональный уровень. Компетенция наднационального органа (Комиссии Таможенного союза - Евразийского экономического сообщества - ЕАЭС) ограничивалась вопросами: а) торговой политики; б) таможенного, технического, антимонопольного регулирования; в) санитарного, ветеринарного и фитосанитарного контроля; г) таможенной статистики. Государства-члены Союза самостоятельны в вопросах денежной политики, согласовании макроэкономической политики, гармонизации вопросов налогового и финансового регулирования. - Со вступлением в силу Договора о ЕАЭС (с 1 января 2015 г.), а также в целях дальнейшего развития государств-членов Союза возможно и целесообразно расширение как границ экономической интеграции, так и ее направлений (новых сфер), в том числе в направлении гуманитарного сотрудничества, более полного развития человеческого потенциала.

- Продолжение работы по совершенствованию действующего законодательства (нормативноправовой базы) в рамках ЕАЭС, в том числе работа над новой редакцией Таможенного кодекса (Таможенный кодекс ЕАЭС) с учетом изменений в финансовой сфере, на рынке труда, в торговых отношениях (деловом обороте). Предстоит до конца 2015 г. осуществить имплементацию в него положений 16 новых международных договоров, регулирующих таможенные правоотношения и 6 проектов международных договоров (в том числе с учетом Соглашения ВТО по упрощению процедур торговли от 11 декабря 2013 г.)ำ, развития современных информационных технологий и создания «единого окна» для подачи документов. - Следует также учитывать, что ранее (18 октября 2011 г.) главы правительств стран СНГ подписали многосторонний договор о зоне свободной торговли, который заменил около 110 действовавших на тот момент двусторонних соглашений о взаимной торговле. Договор вступил в силу 20 декабря 2012 г. и начал действовать в отношениях между РБ, РФ, Украиной, Арменией, Молдовой и Казахстаном (подписали договор также Киргизия, Таджикистан, Узбекистан; Азербайджан и Туркмения оставили за собой право присоединиться к этому Договору).

Конечно, на пути к эффективному функционированию Евразийского экономического союза еще предстоит решить множество проблем и вопросов, однако вектор движения - по пути экономической интеграции, к росту благосостояния людей (например, будет определена единая валюта Союза).

Возможно, что в скором времени движение на этом пути будет допол- нено и парламентским объединением, будет создан парламент ЕАЭС.

Возможно, появится Счетная палата и другие органы. Сам Союз уделит больше внимания социальной проблематике, вопросам сотрудничества в области науки, образования и культуры.

Идея евразийской интеграции (реинтеграции на постсоветском пространстве) поддерживается жителями многих бывших союзных республик. 
Таблица 6

Результаты ответов жителей разных стран в пользу объединения Беларуси, Казахстана и России в Таможенный союз (в процентах)

\begin{tabular}{|c|c|c|}
\hline Страна & $\mathbf{2 0 1 2}$ & $\mathbf{2 0 1 3}$ \\
\hline Россия & $72 \%$ & $67 \%$ \\
\hline Беларусь & $60 \%$ & $65 \%$ \\
\hline Казахстан & $80 \%$ & $73 \%$ \\
\hline Армения & $61 \%$ & $67 \%$ \\
\hline Азербайджан & $38 \%$ & $37 \%$ \\
\hline Киргизия & $67 \%$ & $72 \%$ \\
\hline Молдова & $65 \%$ & $54 \%$ \\
\hline Таджикистан & $76 \%$ & $75 \%$ \\
\hline Узбекистан & $67 \%$ & $77 \%$ \\
\hline Грузия & $30 \%$ & $59 \%$ \\
\hline Туркменистан & - & $50 \%$ \\
\hline Украина & $57 \%$ & $50 \%$ \\
\hline
\end{tabular}

Начиная с 2012 г. Евразийский банк развития (создан в России и Казахстане) проводит регулярный опрос мнения жителей отдельных государств в отношении евразийских интеграционных проектов. Следующий вопрос был задан жителям отдельных стран: «Беларусь, Казахстан и Россия объединились в Таможенный союз, который освободил торговлю между тремя странами от пошлин, и создали Единое экономическое пространство (по сути - единый рынок трех стран).

\footnotetext{
${ }^{1}$ Так, ст. 1 Соглашения по упрощению процедур торговли (2013 г., ВТО) требует, чтобы каждый член ВТО в легкодоступной форме публиковал и информировал правительства стран и предпринимателей о: а) импортных, экспортных и транзитных процедурах, необходимых формах и документах; б) любых видах применяемых ставок пошлин и налогов в связи с импортом и экспортом; в) сборах и пошлинах, налагаемых Правительством страны; г) правилах и оценки стоимости товара для таможенных целей и т. д.
}

Как Вы относитесь к этому решению?»

Результаты ответов суммарно «выгодно» и «очень выгодно» приведены в табл. $6^{1}$ :

Как видно, идея создания Таможенного союза и Евразийского экономического пространства в целом одобряется и выглядит «выгодной» в глазах большинства населения, практически всех, за исключением Азербайджана, стран СНГ, и даже в Грузии.

На это есть разная реакция. Так, США в своей внешней политике выступают против Таможенного союза и ЕАЭС, утверждая, что это является попыткой восстановить доминирование России на постсоветском пространстве и создать союз наподобие СССР. Однако это не пугает ни руководство, ни граждан стран ЕАЭС. 
Схема 2.

Евразийский экономический союз (ЕАЭС) - международная организация региональной экономической интеграции, обладающая международной правосубъектностью.

Союз заключен 29 мая 2014 года в г. Астане (Казахстан).

(Ст. 1 Договора о ЕАЭС)

В рамках ЕАЭС обеспечивается:

1. Свобода движения капиталов, товаров, услуг, капиталов и рабочей силы.

2. Проведение скоординированной согласованной или единой политики в отраслях экономики, определенных Договором о ЕАЭС и международными договорами в рамках Союза.

3. Реализация: а) общепризнанных принципов международного права; б) уважение особенностей политического устройства стран-участниц; в) взаимовыгодное сотрудничество, учет национальных интересов; г) соблюдение конкуренции стран и принципов рыночной экономики; д) функционирование Таможенного союза без изъятий и ограничений (ст. 3 Договора о ЕАЭС).

\begin{tabular}{|l|}
\hline \multicolumn{1}{|c|}{ Евразийский экономический союз действует с 1 января 2015 года. } \\
\hline \multicolumn{1}{|c|}{ Цели ЕАЭС: } \\
\hline \multicolumn{1}{|c|}{} \\
\hline \begin{tabular}{l} 
- создание условий для собственного развития экономик государств-членов в интересах \\
повышения жизненного уровня их населения; \\
- формирование единого рынка товаров, услуг, капиталов и трудовых ресурсов в рамках Союза; \\
- всесторонняя модернизация, кооперация и повышение конкурентоспособности \\
национальных экономик в условиях глобальной экономики (ст. 4 Договора о ЕАЭС). \\
\hline \multicolumn{2}{|c|}{ Право ЕАЭС составляют: } \\
\hline \multicolumn{2}{|c|}{} \\
\hline - Договор о ЕАЭС; \\
- международные договоры, заключенные в рамках Союза; \\
- международные договоры ЕАЭС с третьими странами; \\
- решения и распоряжения Высшего Евразийского экономического совета, Евразийского \\
межправительственного совета и Евразийской экономической комиссии; \\
- приоритет в разрешении противоречий принадлежит Договору о ЕАЭС; \\
- решения высших органов ЕАЭС исполняются государствами-членами в порядке, \\
предусмотренном их национальными законодательствами.
\end{tabular} \\
\hline
\end{tabular}

\begin{tabular}{|l|l|}
\hline \multicolumn{2}{|c|}{ Руководящие органы ЕАЭС (ст. 8 Договора о ЕАЭС) } \\
\hline \multicolumn{2}{|c|}{} \\
\hline $\begin{array}{l}\text { Высший Евразийский экономический совет } \\
\text { (Высший совет) - } \\
\text { входят главы государств }\end{array}$ & $\begin{array}{l}\text { Евразийский межправительственный совет } \\
\text { (Межправительственный совет) - } \\
\text { состоит из глав правительств }\end{array}$ \\
\hline $\begin{array}{l}\text { Евразийская экономическая комиссия } \\
\text { (Комиссия, ЕЭК) - } \\
\text { постоянно действующий регулирующий орган } \\
\text { Союза, его правительств. } \\
\text { Место пребывания - г. Минск. }\end{array}$ & $\begin{array}{l}\text { Суд Евразийского экономического союза (Суд } \\
\text { Поюза) - } \\
\text { Паседает в г. Минске. }\end{array}$ \\
\hline
\end{tabular}

1 Источник: Википедия (Свободная энциклопедия) [Электронный pecypc]. URL: https:// ru.wikipedia.org/wiki/Таможенный_союз_ЕАЭС (дата обращения: 10.09.2015). 
В рамках ЕАЭС действуют (проводятся):

группа ревизоров для осуществления контроля группа инспекторов, осуществляющих за исполнением бюджета Союза

проводятся мероприятия по сбору и обработке статистической информации внешний аудит (контроль) за формированием, управлением и расходованием средств бюджета Союза

\begin{tabular}{|l|l|}
\hline \multicolumn{2}{|c|}{ В рамках ЕАЭС функционируют: } \\
\hline 1. Таможенный союз \\
\hline - & внутренний рынок товаров; \\
$-\quad$ единый таможенный тариф ЕАЭС; \\
- $\quad$ меры регулирования внешней торговли с третьими странами; \\
- $\quad$ единое таможенное регулирование; \\
- перемещение товаров внутри ЕАЭС без таможенного дискриминирования и \\
госконтроля (в т.ч. транспортного, санитарного, ветеринарного и др.). \\
\hline 2. Свободные (специальные, особые) экономические зоны и свободные склады для развития \\
производства, туризма, транспорта и т. д. \\
\hline 3. Внутренний рынок и свободное движение товаров, капиталов, услуг, лиц, и запрет на \\
вывозные таможенные пошлины, платы, сборы, меры не территориального регулирования и \\
антидемпинговые меры.
\end{tabular}

\begin{tabular}{|c|c|}
\hline \multicolumn{2}{|c|}{ Договор о Евразийском экономическом союзе, регулирует вопросы: } \\
\hline $\begin{array}{l}\text { создания руководящих органов Союза, общий } \\
\text { порядок их деятельности, компетенцию; }\end{array}$ & $\begin{array}{l}\text { формирование бюджета Союза и контроля за } \\
\text { его использованием; }\end{array}$ \\
\hline $\begin{array}{l}\text { функционирование Таможенного союза, } \\
\text { создания свободных (специальных) } \\
\text { экономических зон; }\end{array}$ & $\begin{array}{l}\text { регулирование обращения лекарственных } \\
\text { средств и медицинских изделий; }\end{array}$ \\
\hline судебной деятельности, работы Суда ЕАЭС; & таможенного регулирования; \\
\hline $\begin{array}{l}\text { текущего регулирования (технические } \\
\text { регламенты и т.д.); }\end{array}$ & \multirow{2}{*}{$\begin{array}{l}\text { внешней политики Союза, режимов наибольшего } \\
\text { благоприятствования и свободной торговли } \\
\text { (тарифные преференции и регулирование); }\end{array}$} \\
\hline санитарного, ветеринарного и т.п. контроля; & \\
\hline \multirow{3}{*}{$\begin{array}{l}\text { единого экономического пространства, } \\
\text { включая согласованную макроэкономическую } \\
\text { политику, валютную политику, торговлю } \\
\text { услугами, привлечение инвестиций и т.п.; }\end{array}$} & защиты прав потребителей; \\
\hline & $\begin{array}{l}\text { административного сотрудничества между } \\
\text { компетентными органами государств-членов; }\end{array}$ \\
\hline & финансовых рынков; \\
\hline \multirow{2}{*}{$\begin{array}{l}\text { установление общих принципов и правил } \\
\text { конкуренции, в том числе государственного } \\
\text { ценового регулирования; }\end{array}$} & налогов и налогообложения; \\
\hline & деятельности естественных монополий; \\
\hline скоординированной транспортной политики; & \multirow{2}{*}{$\begin{array}{l}\text { взаимодействия государств-членов в } \\
\text { сфере энергетики, формирования общего } \\
\text { энергетического рынка Союза; }\end{array}$} \\
\hline $\begin{array}{l}\text { закупок для государственных и } \\
\text { муниципальных нужд; }\end{array}$ & \\
\hline интеллектуальной собственности; & \multirow{2}{*}{$\begin{array}{l}\text { скоординированной (согласованной) } \\
\text { агропромышленной политики, поддержки } \\
\text { сельского хозяйства со стороны государства; }\end{array}$} \\
\hline промышленной политики; & \\
\hline $\begin{array}{l}\text { сотрудничества в сфере трудовой миграции, прав } \\
\text { и обязанностей работодателей, трудящихся; }\end{array}$ & $\begin{array}{l}\text { переходных и заключительных положений статуса } \\
\text { русского языка как рабочего языка Союза; }\end{array}$ \\
\hline статуса государств-наблюдателей Союза; & \multirow[b]{2}{*}{$\begin{array}{l}\text { порядка опубликования актов ЕАЭС и } \\
\text { действия приложений к Договору о ЕАЭС } \\
\text { (всего 38). }\end{array}$} \\
\hline $\begin{array}{l}\text { разрешения споров через консультации и } \\
\text { переговоры и порядок выхода из Договора о } \\
\text { ЕАЭС; }\end{array}$ & \\
\hline
\end{tabular}




\section{ЛИТЕРАТУРА:}

1. С.Ю. Глазьев, В.И. Чушкин, С.П. Ткачук. Европейский союз и Евразийское экономическое сообщество: сходство и различие процессов интеграционного сотрудничества. М.: ООО ВИКТОР МЕДИА, 2013. 240 с.

2. Глотов С.А. Право Европейского союза в редакции Лиссабонского договора: учебное пособие. М.: Изд-во Международного юридического института, 2010. 452 c.

3. Глотов С.А. Экономическая и политическая интеграция на постсоветском пространстве: от СНГ к ЕврАзЭС и АЕЭС // Сб. тр. Московского нового юридического института. Вып. 7. / Отв. ред. В.И. Дюкарев. М.: Изд-во МНЮИ, 2015. С. 154-260.

4. Декларация о евразийской экономической интеграции от 18 ноября 2011 года. [Электронный ресурс]. URL: http://www.kremlin.ru/supplement/1091 (дата обращения: 10.09.2015).

5. Декларация о формировании Единого экономического пространства Республики Беларусь, Республики Казахстан и Российской Федерации, 9 декабря 2010. [Электронный ресурс]. URL: http://www.kremlin.ru/supplement/802 (дата обращения: 10.09.2015).

6. Договор об учреждении Евразийского экономического сообщества от 10 октября 2000 г., г. Астана. [Электронный pecypc]. URL: http://www.iecp.ru/docs/ agreements/5rus-evr.pdf (дата обращения: 10.09.2015).

7. Договор о Евразийском экономическом союзе, 29 мая 2014 г., г. Астана. [Электронный ресурc]. URL: http://base. garant.ru/70670880/ (дата обращения: 10.09.2015).
8. Единый таможенный тариф Таможенного союза. М.: Проспект, 2010. 760 с.

9. Назарбаев Н.А. Проект о формировании Евразийского союза государств // Независимая газета. 1994. 8 июня.

10. Послание Президента РФ Федеральному Собранию от 04.12.2014 [Электронный ресурс] // КонсультантПлюс [официальный сайт]. URL: www.consultant. ru/document/cons_doc_law_171774/ (дата обращения: 10.09.2015).

11. Право Европейского Союза: учебник для вузов / Под ред. С.Ю. Кашкина. 3-е изд., перераб. и доп. М.: Юрист; Высшее образование, 2010. 1119 с.

12. Путин В.В. Новый интеграционный проект для Евразии - будущее, которое рождается сегодня // Известия. 2011. 3 октября.

13. Регулирование внешней торговли Таможенного союза в рамках ЕврАзЭС: учебное пособие / Под общ. ред. С.Ю. Глазьева и Т.А. Мансурова. М.: Митель-пресс, 2011. 416 с.

14. Сборник нормативных правовых актов в сфере трудовой миграции государств-участников Договора о создании Союзного государства. Минск: БЕЛТА, 2009. 352 c.

15. Статут Суда Евразийского экономического союза. [Электронный ресурc]. URL: http://online.zakon.kz/ Document/?doc_id=31565800 (дата обращения: 10.09.2015).

16. Таможенный кодекс Таможенного союза. [Электронный ресурc]. URL: http:// base.garant.ru/12171455/\#help (дата обращения: 10.09.2015).

17. Толстых В.Л. Курс международного права: учебник / В.Л. Толстых. М.: Волтерс Клувер, 2010. 1056 с. 